\section{B A Institute of \\ YK Business Administration \\ 六下 \\ Karachi \\ Leadership and Ideas for Tomorrow}

Business Review

Volume 2 Issue 2 July-December 2007

7-1-2007

\title{
Analyzing construction-related market trends in APEC countries using GIS
}

\author{
Low Sui Pheng \\ National University of Singapore \\ Benny Raphael \\ National University of Singapore \\ Faisal Manzoor Arain \\ Institute of Business administration, Karachi, Pakistan
}

Follow this and additional works at: https://ir.iba.edu.pk/businessreview

Part of the Business Intelligence Commons, Construction Engineering and Management Commons, Geographic Information Sciences Commons, Nature and Society Relations Commons, Real Estate Commons, and the Urban Studies and Planning Commons

\section{c) (i)}

This work is licensed under a Creative Commons Attribution 4.0 International License.

\section{Recommended Citation}

Pheng, L. S., Raphael, B., \& Arain, F. M. (2007). Analyzing construction-related market trends in APEC countries using GIS. Business Review, 2(2), 29-46. Retrieved from https://doi.org/10.54784/ 1990-6587.1388

This article is brought to you by iRepository for open access under the Creative Commons Attribution 4.0 License and is available at https://ir.iba.edu.pk/businessreview/vol2/iss2/3. For more information, please contact irepository@iba.edu.pk. 


\title{
ARTICLE
}

\section{Analyzing Construction-related Market Trends in APEC Countries using GIS}

\author{
Low Sui Pheng \\ National University of Singapore \\ Benny Raphael \\ National University of Singapore \\ Faisal Manzoor Arain \\ Institute of Business Administration, Karachi, Pakistan \\ Susan Soh \\ National University of Singapore
}

\section{ABSTRACT}

GIS (Geographical Information System) is a means of representing data in digital form that has been used increasingly in various domains. GIS has the ability to capture, model, manipulate, retrieve, analyze and present geographically referenced data. In managing overseas building projects, research and analysis are especially crucial. It is necessary to collect enough information of the country that is related to the rule of law, government policies, and the performance of individual economic sectors, among other things. Although GIS has been shown to be a useful tool in various types of planning and management, it has not been used so far for international marketing research in the construction industry. This study therefore harnesses the potential of GIS software to present various statistical data relating to the construction industry in a $3 D$ format so as to better improve the understanding of the data collected. The focus of this study is on the Asia-Pacific Economic Cooperation (APEC) Forum's countries. The GIS analysis covers the variables of Gross Domestic Product (GDP), construction, manufacturing, agriculture and population to determine how various economic sectors are related to one another in APEC countries. Summaries of sizes of construction markets of APEC countries and their growth trends were established figuratively using GIS screenshots in this study. This will assist construction firms in making decisions related to investments in APEC countries. Among other findings, this study shows that in terms of GDP and construction volume, Japan and the United States were the strongest among APEC countries throughout the 20-year period between 1985 and 2004. Brunei and Papua New Guinea have the lowest GDP and construction volume in the same period.

Keywords: GIS, APEC, International Construction Markets, Business Trends 


\section{INTRODUCTION}

$\mathrm{W}$ hen venturing overseas, the first thing that contractors require is information. In managing overseas projects, research and analysis are especially crucial. It is necessary to collect enough information of the country that is related to the rule of law, government policies, and the performance of individual economic sectors, among other things.

In the beginning, information was considered as power. Today, information is essential for survival. Merely collecting information is not enough; accessibility and the proper use of information are vital. Information helps to reduce uncertainties through the appropriate interpretation of data. In any businesses, information is a pre-requisite for making decisions confidently. It is especially important in the construction industry where success can be greatly influenced by fluctuations in the general economy. Due to the unpredictable nature of the construction industry, sensible people are turning to statistical data as a source of information to find out the past, analyze the present and forecast the future (Turin 1970).

According to MacDonald (1980), the information gathered can be used to develop long-term strategies and short-term tactical decisions as well as for use as marketing research information for the occasional one-off marketing problems. The two main tasks concerned with market analyses in both the domestic and international markets are to evaluate the volumes and growth potentials of existing markets as well as future markets.

With the advancement of technology, accessing information has progressed from the traditional paper form to that of the Internet. A majority of the information is now given in digital form. GIS (Geographical Information System) is a means of representing data in digital form that has been used increasingly in various domains. GIS has the ability to capture, model, manipulate, retrieve, analyze and present geographically referenced data. It is playing an increasingly important role in the real estate and construction industry. International construction contracting is a risky business. It is therefore important to collect vital construction statistical data of various countries and perform trend analysis to better understand the international construction market.

GIS has been shown to be a useful tool in various types of planning and management. However, it has not been used so far for international marketing research in the construction industry (Low, 1993). Statistical data is commonly represented by $2 \mathrm{D}$ charts and graphs traditionally. Many analysts have overlooked the opportunity of using GIS to represent such data in a 3D format to thus enrich the information gathered. 
This study harnesses the potential of GIS software to present various statistical data relating to the construction industry in a $3 \mathrm{D}$ format so as to better improve the understanding of the data collected. The focus of this study is on the Asia-Pacific Economic Cooperation (APEC) Forum's countries. The GIS analysis covers the variables of Gross Domestic Product (GDP), construction, manufacturing, agriculture and population to determine how various economic sectors are related to one another in APEC countries.

Statistical data between 1985 and 2004 was collected from various library databases and statistical yearbooks of the United Nations (UN) and World Bank (WB). The SPSS Statistical Package was used to perform regression analysis to further investigate the correlations between construction and other economic sectors. The data was further transformed into 3D formats using GIS software to show the trends across APEC countries.

\section{GEOGRAPHIC INFORMATION SYSTEM (GIS)}

Geographic Information System (GIS) uses stored data to create customized computer-based maps showing locations and attributing information about objects of interest to a decision maker. It can be used to create decision support system (DSS) for use with specific decision needs. GIS software is widely used in various stages of planning management, and is also an invaluable asset in marketing information system. Wikipedia, an online encyclopedia, describes a GIS as a system for creating and managing spatial data and associated attributes. In the strictest sense, it is a computer system capable of integrating, storing, editing, analyzing, and displaying geographically-referenced information. In a more generic sense, GIS is a "smart map" tool that allows users to create interactive queries (user created searches), analyze the spatial information, and edit data (Wikipedia, 2005).

One of the earliest definitions of GIS came from Tomlinson (1972) who stated that GIS is not a field in itself but rather the common ground between information processing and the many fields utilizing spatial analysis techniques. The modern history of GIS dates from the early 1980s when the price of sufficiently powerful computers fell below a critical threshold. As a result, GIS had increased in its capacity over the years with better abilities in storing, retrieving, inputting and displaying data. With the continuously widespread of GIS and the advancement in technology, more functions were integrated into GIS which have significantly improved its capabilities. GIS is now associated with modeling and problem solving.

Today, GIS is seen as a system of computer hardware, software and procedures designed to support the capture, management, manipulation, analysis and display of spatially referenced data for solving complex planning and management problems. 
In the late 1990s, in keeping pace with the ever constant upgrading of technology, GIS software had added statistical analysis to its already impressive array of capabilities. The modern-day GIS software now integrates common database operations, such as query and statistical analysis, with maps.

The first GIS developed was the Canada Geographic Information System, designed in the mid 1960s to identify the nation's land resources and their existing and potential uses. Since then, GIS can now be used for a wide variety of functions ranging from tracking vehicles on the highways to identifying hot spots for mosquito outbreaks or pandemics (Longley et al., 2001).

In the area of market studies, Wyatt and Ralphs (2003) explained that GIS can perform geographical analysis that was used to support decision-making in different market sectors such as retail, leisure, finance and property. Demographic data was analyzed to produce statistical information about the population groups, customer profiling, store location planning and development. This in turn enables the different sectors to define customer locations and identify catchment areas. In the real estate industry, it is important and crucial to have an accurate market analysis. GIS can assist in property market analysis through feasibility studies for investing and developing a particular property at the correct time in the most suitable location. These help to identify profitable investment locations. GIS can also help to reveal property trends that assist residential and commercial property investment decisionmaking using choropleth maps.

Publications and research into the applications of GIS in the construction industry are, however, few and far between. Most applications of GIS in construction are for large construction projects over a long duration covering a large area where there is a need to consider factors other than construction and design such as environmental effects, property boundaries, routing options and other factors. For instance, GIS was used in the pipeline route selection process for the Metropolitan Water District of Salt Lake and Sandy to supply drinking water approximately $9 \mathrm{~km}$ through mostly developed areas of two communities. In this case, GIS allowed for a logical selection and ranking of alternatives, resulting in one final alignment corridor that was acceptable to all stakeholders in the project (Luettinger and Clark, 2005). Furthermore, GIS was also useful in analyzing the suitability for construction aggregates recycling sites using regional transportation network and population density features. It can measure the spatial relations between existing aggregates recycling sites, transportation networks, population density distribution, and natural aggregates production sites. This data-driven analysis used regional relationships to quickly delineate the general areas most likely to be of interest to the construction and aggregates industries as sites for both current and future recycled aggregates production, and to the land management community for planning and zoning evaluation were related to future recycled aggregates production (Robinson Jr. and Kapo, 2004). 
By extension, GIS can be used in site investigation by using a database for the storage of descriptive soil data. With the aid of GIS, construction firms can relate this data to a display of the corresponding locations of boreholes, and a graphical user interface (GUI) to facilitate the input, query, and output of data, in addition to drawing bore logs. Additionally, GIS can also relate descriptive project information to graphical displays showing geographic locations on digital maps on a computer screen. This is useful for design-build organizations who can benefit from a single database for foundations analysis, design, and construction planning; hence, enabling the integration of design and construction.

Cheng and O'Connor (1996) developed a system named ArcSite, which was a GIS integrated with database management systems (DBMSs) to assist designers in identifying suitable area to locate temporary facilities. This automated site layout system proposed a knowledge acquisition method to systematically acquire and interpret experts' knowledge and experience in site planning. ArcSite demonstrated that GIS is a promising tool for solving construction layout problems. This opened up a new way of thinking in the management of spatial information for construction planning and design.

The concept of Marketing Information Systems (MKIS) originated in the 1960s as a technique for applying new (at that point of time) data processing technologies to marketing-specific decisions (Low, 1993). GIS was able to provide value for making marketing decisions by providing a way to analyze internal or external marketing intelligence data in a format particularly suited for this purpose. In addition, GIS also provided the ability to integrate both internal and external marketing intelligence data to greatly improve the effectiveness of marketing decisions (Low and AbdulAziz, 1993).

According to Hess, Rubin and West Jr. (2002), there was undoubtedly a role for GIS in marketing since it fit well into the four elements of the marketing mix. The benefits of integrating GIS into MKIS were their ability to provide map-based presentations of data relationships for decision makers and its ability to integrate disparate data using geography as a common key.

The Arc View GIS 3.2 software was used in the study presented in this paper. It is capable of mapping densities and producing results in 3D formats. It shows density levels by mapping the locations of features. However, in areas with many features, it may be difficult to differentiate and compare between densities. A density map, however, allows for measuring features using a uniform area unit, such as acres or square miles, thus giving a clear representation of the distribution.

Mapping density is especially useful when mapping areas, such as census tracts or counties, which vary greatly in size. On maps showing the number of people per 
census tract, the larger tracts may have more people than smaller ones. But some smaller tracts mayhave more people per square mile, i.e. a higher density.

\section{THE APEC FORUM}

The Asia-Pacific Economic Cooperation (APEC) Forum was established in 1989 initially with only twelve members. The main objectives of APEC are to further improve economic growth and prosperity, and to strengthen the Asia-Pacific community. It is the leading forum for facilitating economic growth, cooperation, trade and investments in the Asia-Pacific region.

APEC is unlike the World Trade Organization (WTO) or other multilateral trade bodies, as it is the only inter-governmental grouping in the world that does not require binding commitments or treaty obligations from its member countries. Hence, any decisions made within APEC are reached by consensus and commitments undertaken on a voluntary basis.

APEC has worked to reduce tariffs and other trade barriers across the Asia-Pacific region, creating efficient domestic economies and dramatically increasing exports. Free, open trade and investments facilitate economic growth, hence creating jobs and providing even greater opportunities for international trade and investments. Furthermore, free and open trade helps to lower costs of production to reduce prices of goods and services to benefit everyone. In addition, APEC also created an environment for the safe and efficient movement of goods, services and people across borders in the region, through policy alignment and economic and technical cooperation (APEC, 2005).

Currently, APEC consists of twenty-one members who are referred to as the "Members Economies." They include Australia (1989), Brunei Darussalam (1989), Canada (1989), Chile (1994), China (1991), Hong Kong (1991), Indonesia (1989), Japan (1989), South Korea (1989), Malaysia (1989), Mexico (1993), New Zealand (1989), Papua New Guinea (1993), Peru (1998), Philippines (1989), Russia (1998), Singapore (1989), Chinese Taipei (1991), Thailand (1989), United States (1989) and Vietnam (1998). The year in brackets after each country refers to the year in which that country joined APEC. The global locations of APEC member countries are shown in Figure 1.

In general, the services sector has been the key performer in this region. It generated significant economic growth, trade and investments within the Asia-Pacific region. In order to encourage further growth and development in the services sector, APEC's Group on Services (GOS) works on trade and investment liberalization and facilitates issues related to trade in services, and coordinates APEC's work in this area. The GOS works in close collaboration with four service-related Working 
Groups; Telecommunications and Information; Transportation; Tourism; and Energy (APEC Secretariat, 2004).

The GIS analysis covering various economic variables in APEC member countries is presented below in $3 \mathrm{D}$ formats.

\section{CONSTRUCTION TRENDS}

In absolute terms, Japan had the highest construction volume worth US $\$ 307.81$ billion in 1985. This was followed by the United States with US $\$ 251.40$ billion. Brunei and Papua New Guinea had the lowest construction volume among APEC countries with US\$0.10 billion and US\$0.11 billion respectively in 1985 .

Japan also had the highest average construction volume of US $\$ 426.49$ billion between 1985 and 2004. The United States was in second position with US\$335.36 billion during this period of time. Papua New Guinea had the lowest average construction volume of US $\$ 0.18$ billion. Brunei, with US\$0.27 billion, was just slightly ahead of Papua New Guinea between 1985 and 2004.

The United States, with US\$478.56 billion, had the highest construction volume in 2004. Japan followed closely behind with US $\$ 419.13$ billion. Papua New Guinea had the lowest construction volume of US\$0.19 billion and Brunei the second lowest with US\$0.47 billion of construction volume in 2004 among all APEC countries.

In so far as the mean annual growth for construction volume between 1985 and 2004 is concerned, the United States had the highest value, with a total of US\$11.96 billion, with Japan following behind with a total of US\$5.86 billion. New Zealand and Papua New Guinea had an average of zero annual growth for construction volume between 1985 and 2004. Figure 2 summarizes the mean annual growth of construction volume in APEC countries between 1985 and 2004 using GIS screenshots. In Figure 2, the screenshot on the left presents a $3 \mathrm{D}$ view from the western hemisphere, while that on the right presents a similar $3 \mathrm{D}$ view from the eastern hemisphere.

\section{GDP TRENDS}

The United States' GDP of US\$556.35 billion was the highest among APEC countries in 1985. Japan took the second position with a GDP of US\$388.59 billion. Papua New Guinea and Brunei had the lowest GDP with US\$0.29 billion and US $\$ 0.47$ billion respectively in 1985 among all APEC countries.

Between 1985 and 2004, the United States had the highest average GDP of US $\$ 747.72$ billion, with Japan following behind in second position with US\$513.71 
billion. Papua New Guinea and Brunei had the lowest average GDP of US\$0.41 billion and US $\$ 0.52$ billion respectively among all APEC countries between 1985 and 2004.

The United States' GDP of US\$963.36 billion was the highest among APEC countries in 2004. Japan was in second position with US\$576.24 billion. In 2004, Papua New Guinea and Brunei had the lowest GDP among all APEC countries with US $\$ 0.46$ billion and US $\$ 0.62$ billion respectively.

In so far as the mean annual growth of GDP between 1985 and 2004 is concerned, the United States' value of US $\$ 21.42$ billion was the highest among all APEC countries. Japan's value of US $\$ 9.88$ billion was in second position. Russia had a negative growth of -US $\$ 0.57$ billion. This accounts for the depression on the GIS screenshots shown in Figure 3.

\section{POPULATION TRENDS}

China (1.05 billion) had the highest population among all APEC members in 1985 . This was followed by the United States (238 million) in second position. Brunei $(200,000)$ had the lowest population followed by Singapore $(2.4$ million) with the second lowest population among all APEC countries in 1985.

China (1.19 billion) also had the highest average population among all APEC countries between 1985 and 2004. The United States (265 million) was in second position. Brunei had the lowest average population of about 300,000 people between 1985 and 2004.

China (1.29 billion) had the highest population among all APEC countries in 2004. The United States (293 million) and Indonesia (223 million) were in second and third position respectively. In 2004, Brunei $(400,000)$ was still the nation with the lowest population among all APEC countries. Singapore (4.2 million) was in the second lowest position in 2004 .

In so far as the mean annual growth of population between 1985 and 2004 is concerned, China and Indonesia occupied the first and second position respectively among all APEC countries. As shown in Figure 4, Brunei, New Zealand, Philippines and Russia seemed to record negligible growth during this period of time.

\section{AGRICULTURE TRENDS}

In so far as the mean annual growth of agriculture between 1985 and 2004 is concerned, China has the highest value of US\$6.7 billion among all APEC countries. The United States was in second position with US $\$ 0.81$ billion. As indicated by the 
depression shown in Figure 5, many countries such as Hong Kong, Japan, Russia, Singapore and Chinese Taipei reflected negative figures; with Japan being the lowest with -US\$2.77 billion among all APEC countries between 1985 and 2004.

\section{MANUFACTURING TRENDS}

In so far as the mean annual growth of manufacturing between 1985 and 2004 is concerned, China has the highest value of US\$2.87 billion among all APEC countries. Canada was in second position with US\$0.96 billion. Three countries have negative values; namely Hong Kong, South Korea and the United States. As shown in Figure 6, the United States had the largest deficit of -US\$1.07 billion during this period of time, which accounted for the noticeable depression in the GIS screenshot. As shown in Figure 6, Australia and Papua New Guinea appeared to record negligible growth during this period of time.

\section{RELATIONSHIP BETWEEN CONSTRUCTION AND AGRICULTURE}

The SPSS was used to perform regression analysis between construction and agriculture for APEC countries for the period between 1985 and 2004. The analysis seemed to suggest that there is a relationship between construction and agriculture in 12 APEC countries. As shown in Figure 7, among the 12 APEC countries where the relationship appeared to be in place, only four countries posed very strong relationship with $\mathrm{r}^{2}$ value greater than 0.85 . These four countries are Canada (0.86), Chile (0.91), China (0.94) and Peru (0.97).

\section{RELATIONSHIP BETWEEN CONSTRUCTION AND MANUFACTURING}

Regression analysis was performed between construction and manufacturing for APEC countries using SPSS for the period between 1985 and 2004. The analysis showed 13 countries that seemed to have a relationship between construction and manufacturing with $\mathrm{r}^{2}$ greater than 0.40. As shown in the GIS screenshot in Figure 8, among these 13 countries, China (0.99), Chile (0.98), Peru (0.96), Canada (0.94) and the Philippines (0.85) appeared to have the strongest relationship between construction and manufacturing. Among these 13 countries, a weaker relationship between construction and manufacturing was found in Papua New Guinea and Singapore where their $\mathrm{r}^{2}$ values were around 0.40 .

\section{RELATIONSHIP BETWEEN CONSTRUCTION AND GDP}

SPSS was used to perform regression analysis between construction and GDP for APEC countries. The analysis suggested that 17 countries appeared to have a relationship between construction and GDP with $\mathrm{r}^{2}$ greater than 0.40 . As shown in the GIS screenshot in Figure 9, there is strong relationship between construction and 
GDP in Canada (0.98), Chile (0.96), China (0.99), Mexico (0.96), the Philippines $(0.91)$ and Vietnam (0.90). The analysis seemed to suggest that no such relationship occurred in Japan, New Zealand, Chinese Taipei and Thailand.

\section{RELATIONSHIP BETWEEN CONSTRUCTION AND POPULATION}

SPSS was used to perform regression between construction volume and population for APEC countries. The analysis seemed to suggest a relationship between construction and population in 14 countries with $\mathrm{r}^{2}$ greater than 0.50 . The relationship was strongest in Chile (0.96), Canada (0.91) and Vietnam (0.94). As shown in the GIS screenshot in Figure 10, seven APEC countries have $r^{2}$ less than 0.40. These are Australia, Japan, New Zealand, Papua New Guinea, Russia, Chinese Taipei and Thailand.

\section{CONCLUSION}

Using GIS software to represent various statistical data in a 3D format gives a better and clearer understanding of data. Regression analyses are useful in bringing out relationships between construction and other economic sectors. Summaries of sizes of construction markets of APEC countries and their growth trends were established figuratively using GIS screenshots in this study. This will assist construction firms in making decisions related to investments in APEC countries.

The key objective of this paper is to demonstrate how GIS may be applied for analyzing international construction markets and their associated market trends. Because of words limitations, no attempt was made to explain the trends in greater details reported earlier.

In terms of GDP and construction volume, Japan and the United States were the strongest among APEC countries throughout the 20-year period between 1985 and 2004. Brunei and Papua New Guinea have the lowest GDP and construction volume in the same period.

In the same 20-year period, the most populated country in APEC was China, followed by the United States. Brunei had the lowest population while Singapore had the second lowest population among APEC countries.

China is an important player in the global economic arena. There is an increasing trend in construction in China. China also has the highest mean annual growth in its manufacturing and agriculture sectors.

From the regression analysis, it appears that the construction industry does seem to have some relationships with GDP, agriculture, manufacturing and population. GDP 
appears to be the most important parameter; when a country has high GDP, its construction volume would seem to be correspondingly high as well.

In the context of this study, it must, however, be noted that global statistical data may be unreliable, especially in the less developed countries. The infrastructure available for accurate data collection in each country therefore governs the degree of confidence in the analysis. The tendency for less developed countries to manipulate their submissions for their own benefits cannot be ruled out. This should be recognized accordingly in the interpretations of all results.

A further limitation of this study has been the non-availability of data related to the construction types which made up the final figures used. This is because construction comprises not only of new buildings and civil engineering works but also diverse activities of both maintenance and retrofitting. As Turin (1969) noted, national account statistics is an inadequate tool for analyzing the total gross output of construction. This is because the contribution of construction to GDP includes maintenance and repairs but accounts only for the value added. This problem is compounded further due to the fact that a number of countries do not regularly collect accurate information on the total output of the construction industry.

Only a narrow range of variables that are considered to be the most appropriate were chosen for this analysis. In addition, data is unavailable for some years during the study period, hence average or pro-rated data were extrapolated to fill in the gaps. This will increase the inaccuracy of statistical data of the particular countries. However, care was taken to include the most recent data available in the analysis.

This study is limited only to APEC member countries. Further research is recommended for all the countries in the world to provide a complete international marketing information system for the global construction industry.

\section{REFERENCES}

APEC (2005) About APEC, Asia-Pacific Economic Co-operation Forum (retrieved $27^{\text {th }}$ December 2005 from http://www.apecsec.org.sg/apec/about_apec.html).

APEC Secretariat (2004) APEC Energy Statistics 2002, The Energy Data and Modelling Centre The Institute of Energy Economics, Japan.

Cheng M Y and O'Connor J T (1996) ArcSite: Enhance GIS For Construction Site Layout, Journal of Construction Engineering and Management, 122(4):329-336.

Hess R L, Rubin R S and West Jr. L A (2002) Geographic information systems as a marketing information system technology, Decision Support System, 38(2):197-212.

Longley P A, Goodchild M F, Maguire D J and Rhind D W (2001). Geographic Information Systems and Science, John Wiley \& Sons Ltd: Singapore. 
Low S P (1993) Marketing research for the Global Construction industry, Singapore University Press: Singapore.

Low S P and Abdul-Aziz A R (1993) Competitive \& Marketing Strategies For The Global Construction Industry, Trade Link Media Pte Ltd: Singapore.

Luettinger J and Clark T (2005) Geographic information System-based Pipline Route Selection Process, Journal of Water Resources Planning and Management, 131(3):193-200.

McDonald M H B (1980) Marketing Information Systems: A Review, Singapore Management Review, 2(1):30-43.

Robinson G R and Kapo K E (2004) A GIS analysis of suitability for construction aggregate recycling sites using regional transportation network and population density features, Resources, Conservation and Recycling, 42(4):351-365.

Tomlinson R F (ed.) (1972) Geographical Data Handling, IGO Commission on Geographical Data Sensing and Processing, Ottawa.

Turin D A (1969) The construction industry: Its Economic Significance and Its Role in Development, Building Economics Research Unit, University College Environmental Research Group, London.

Wikipedia (2005) The Free Encyclopedia, (retrieved $23^{\text {rd }}$ December 2005 from http://en.wikipedia.org).

Wyatt P and Ralphs M (2003) GIS in Land and Property Management, Spon Press: London.

"This (Drucker) business philosopher", "management guru", this "man who invented the corporate society" is morally uneasy with the fire of American striving, the manifest content of the American Dream."

Jack Beatty 


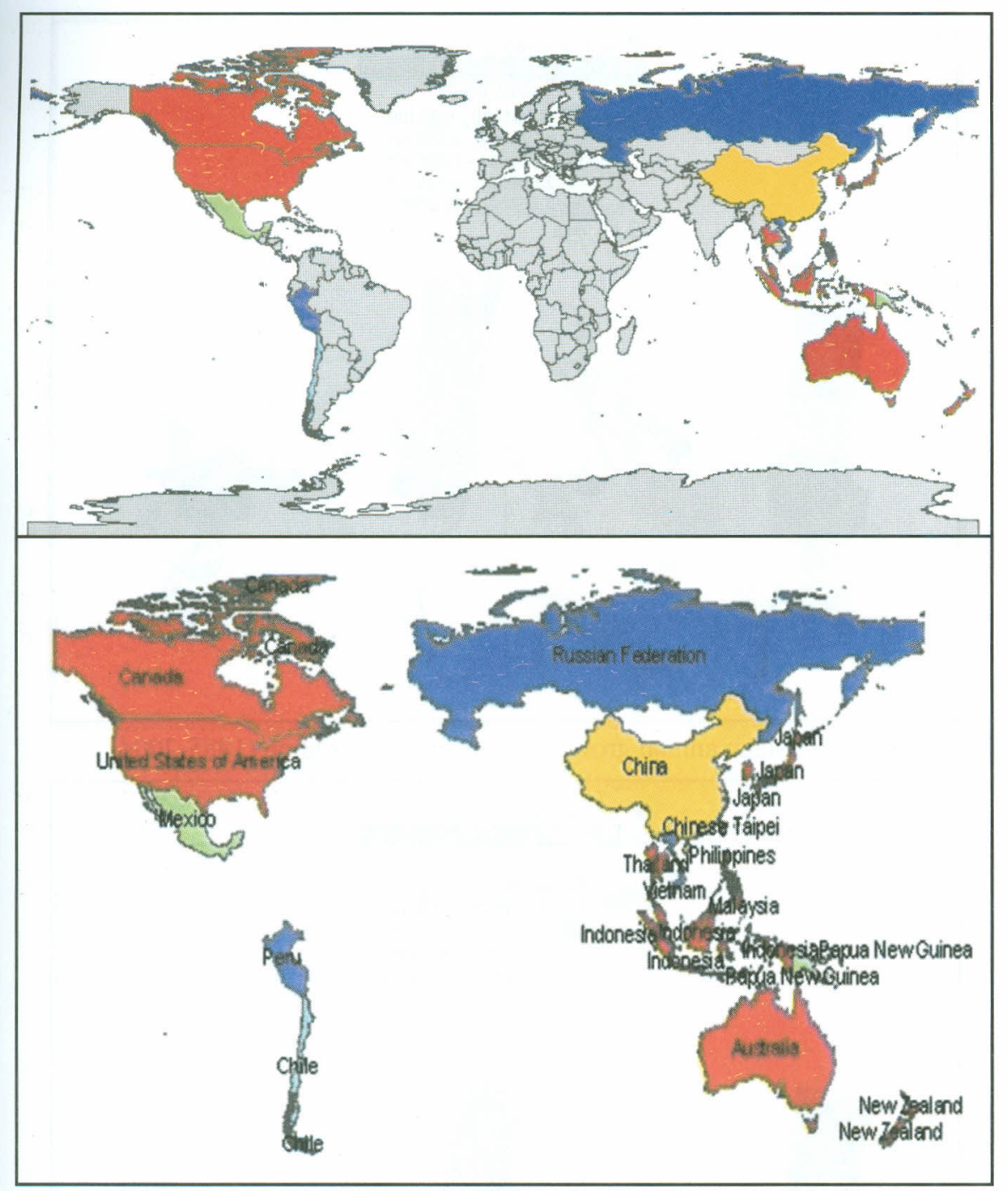

Figure $1 \mathrm{APEC}$ member countries and their global locations 


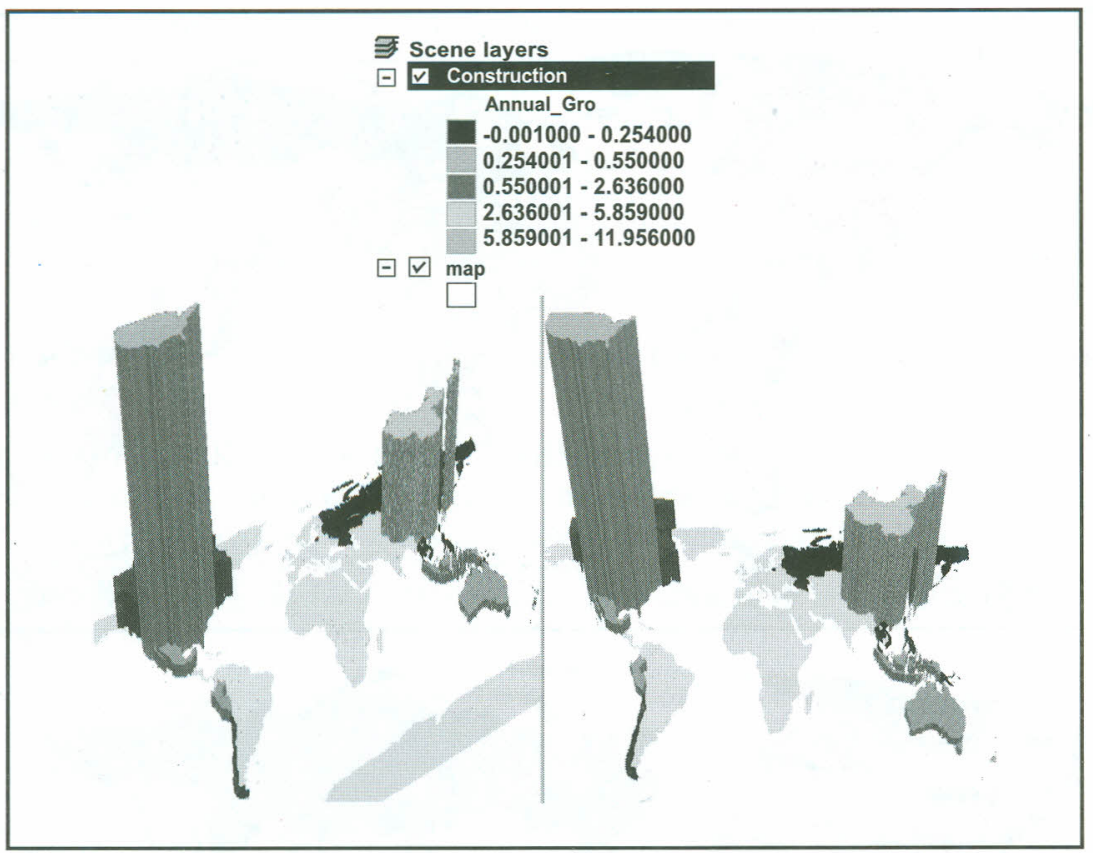

Figure 2 Mean annual growth of construction volume (1985-2004)

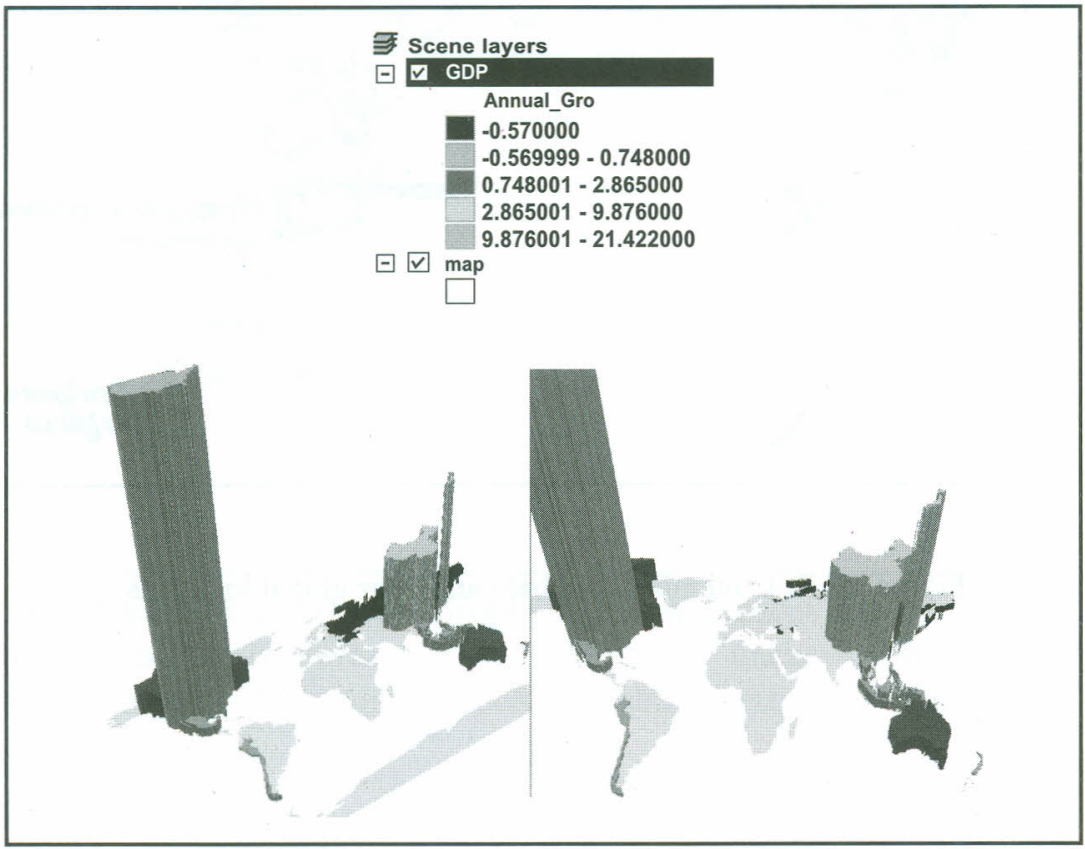

Figure 3 Mean annual growth of GDP (1985-2004)

\section{2}

Published by iRepository, June 2021 


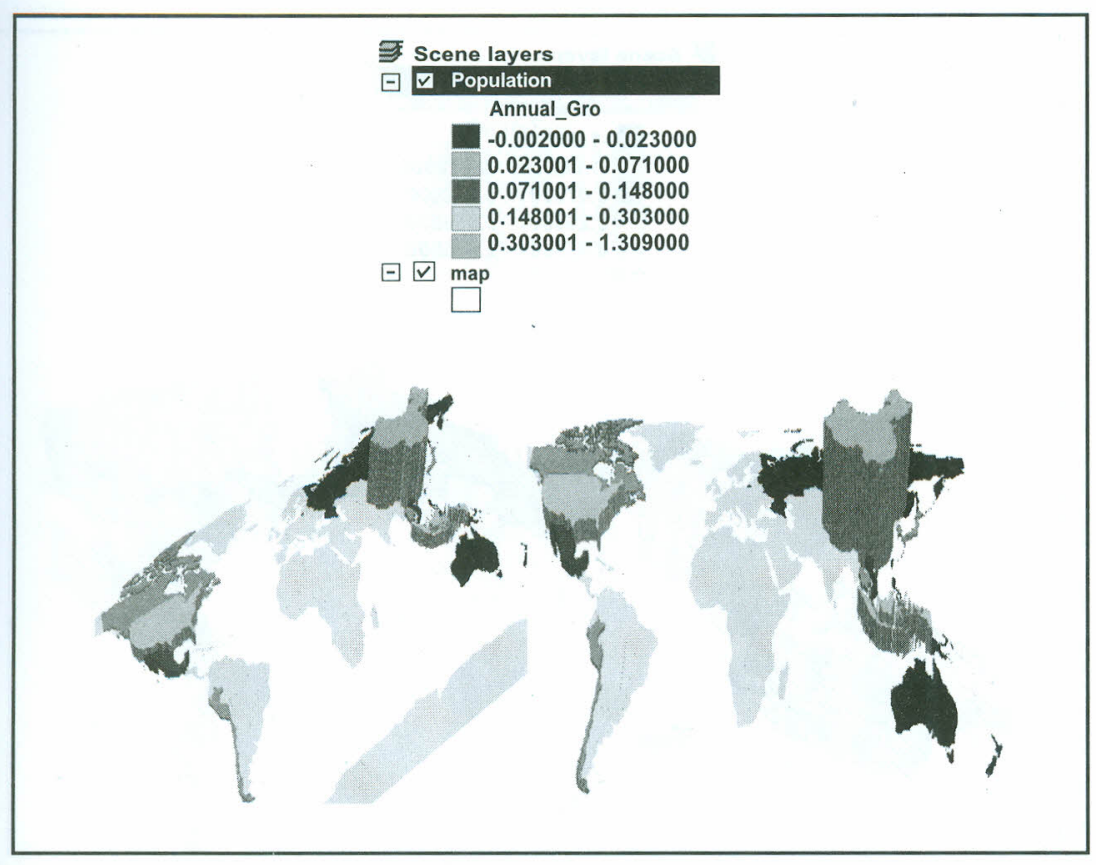

Figure 4 Mean annual growth of population (1985-2004)

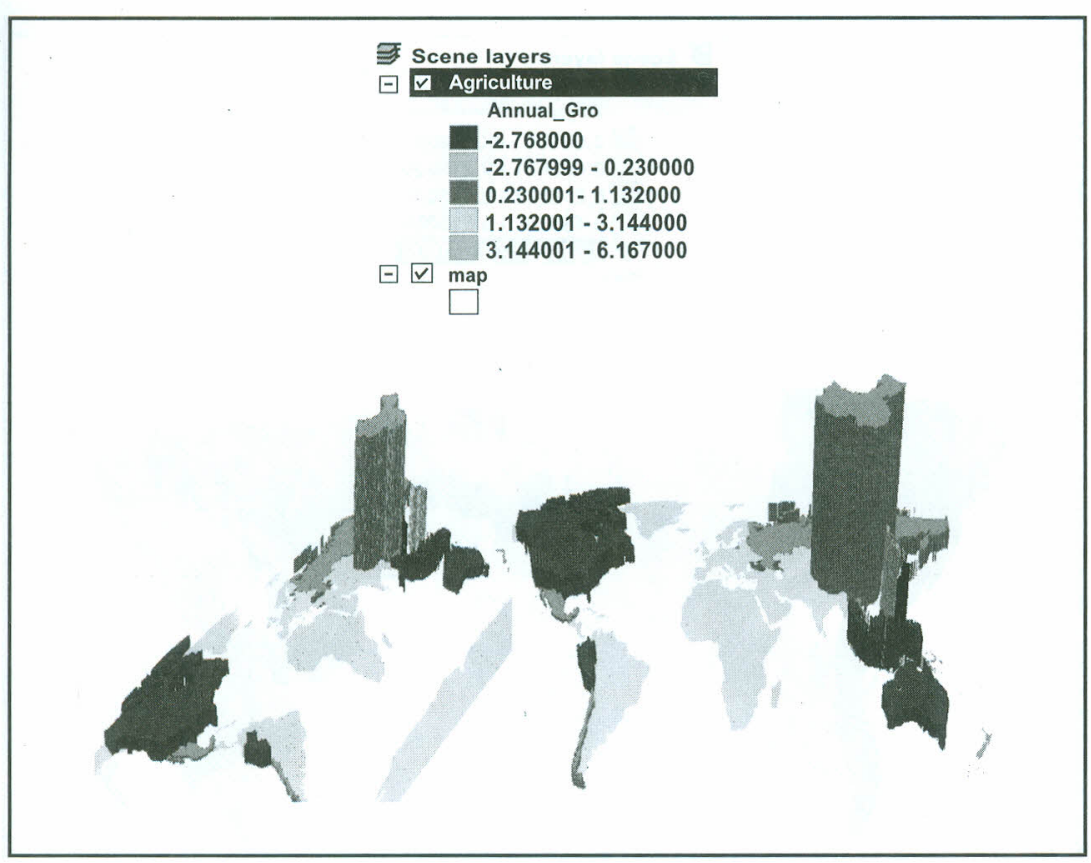

Figure 5 Mean annual growth of agriculture (1985-2004) 


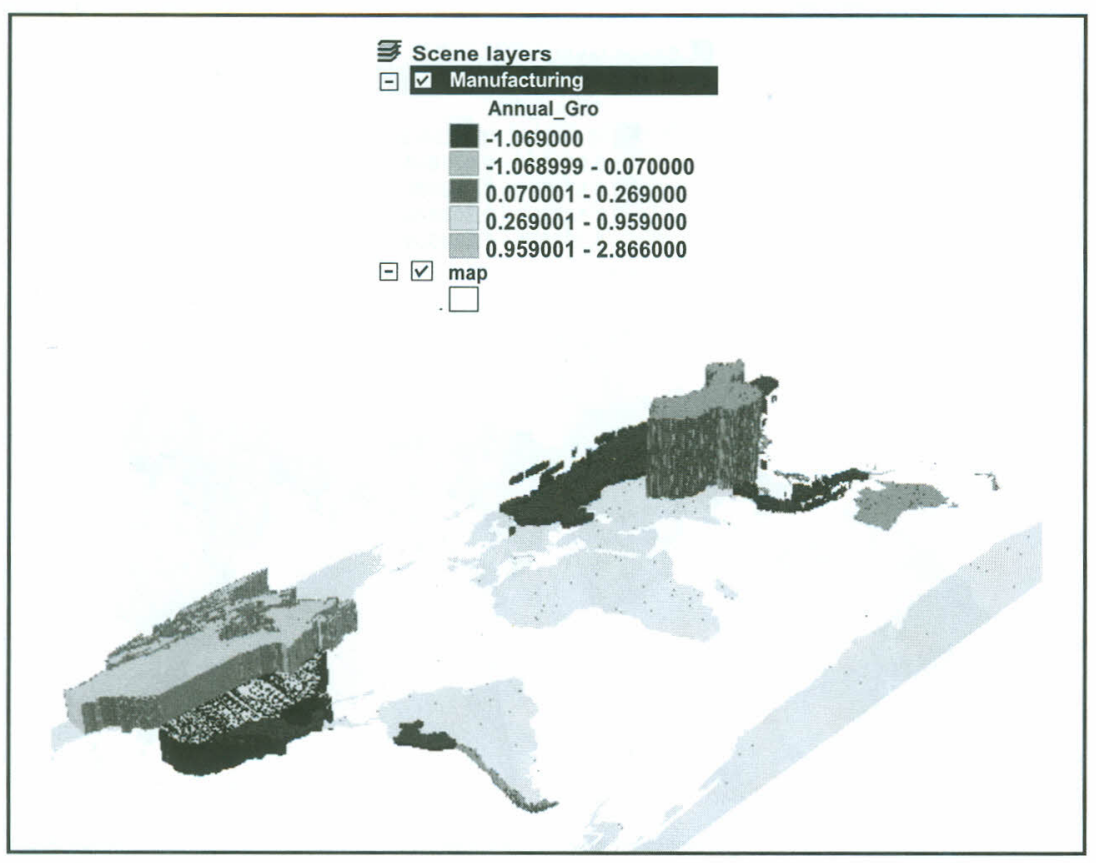

Figure 6 Mean annual growth of manufacturing (1985-2004)

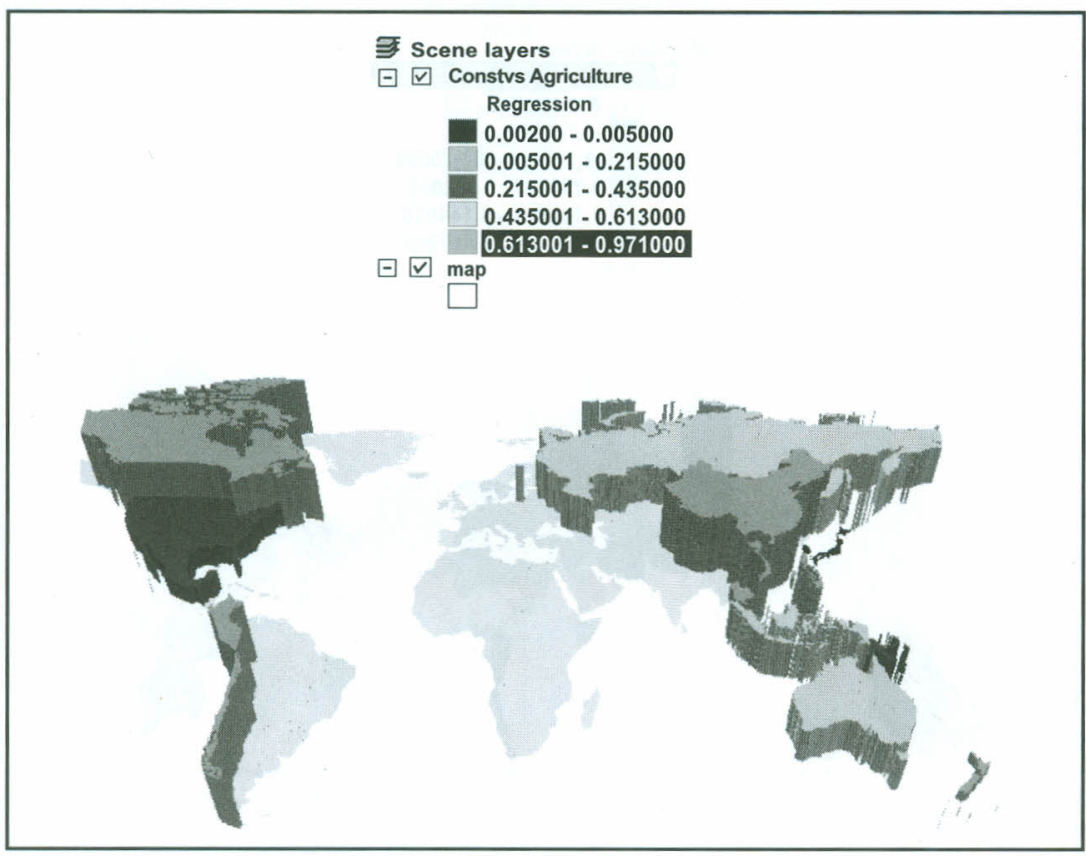

Figure 7 Relationship between construction and agriculture 


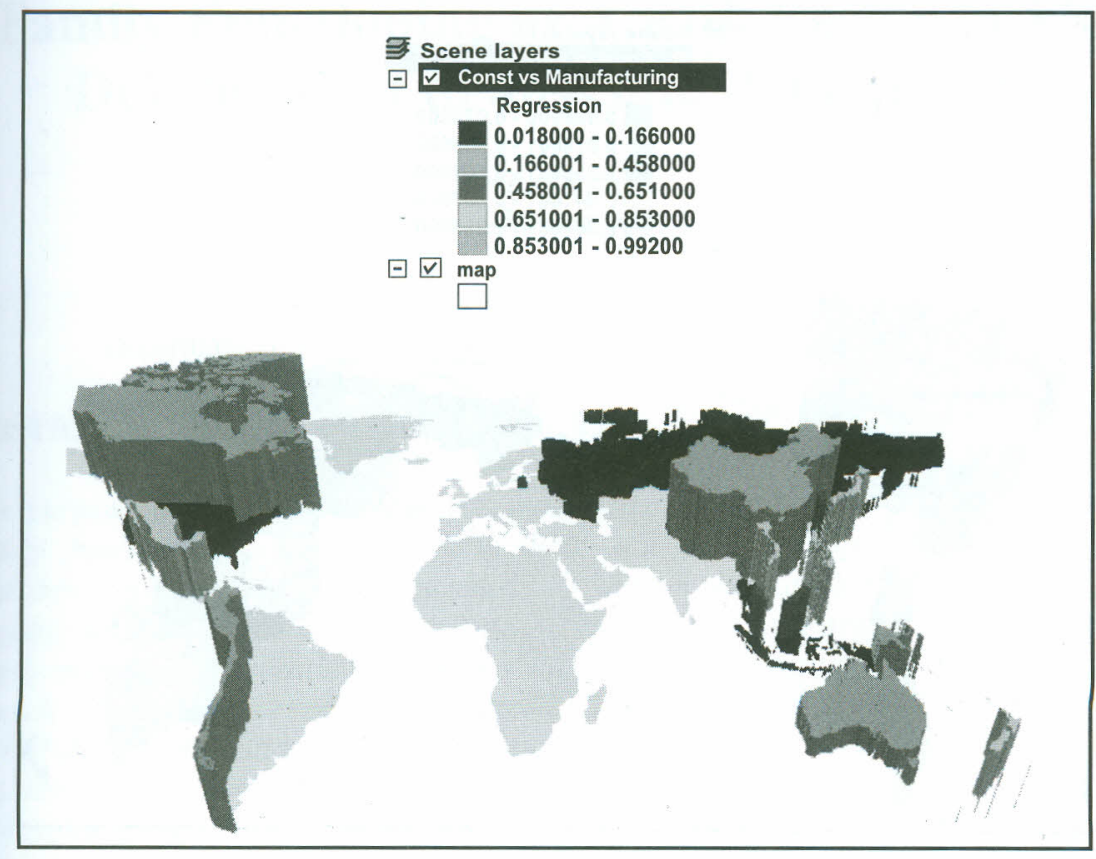

Figure 8 Relationship between construction and manufacturing

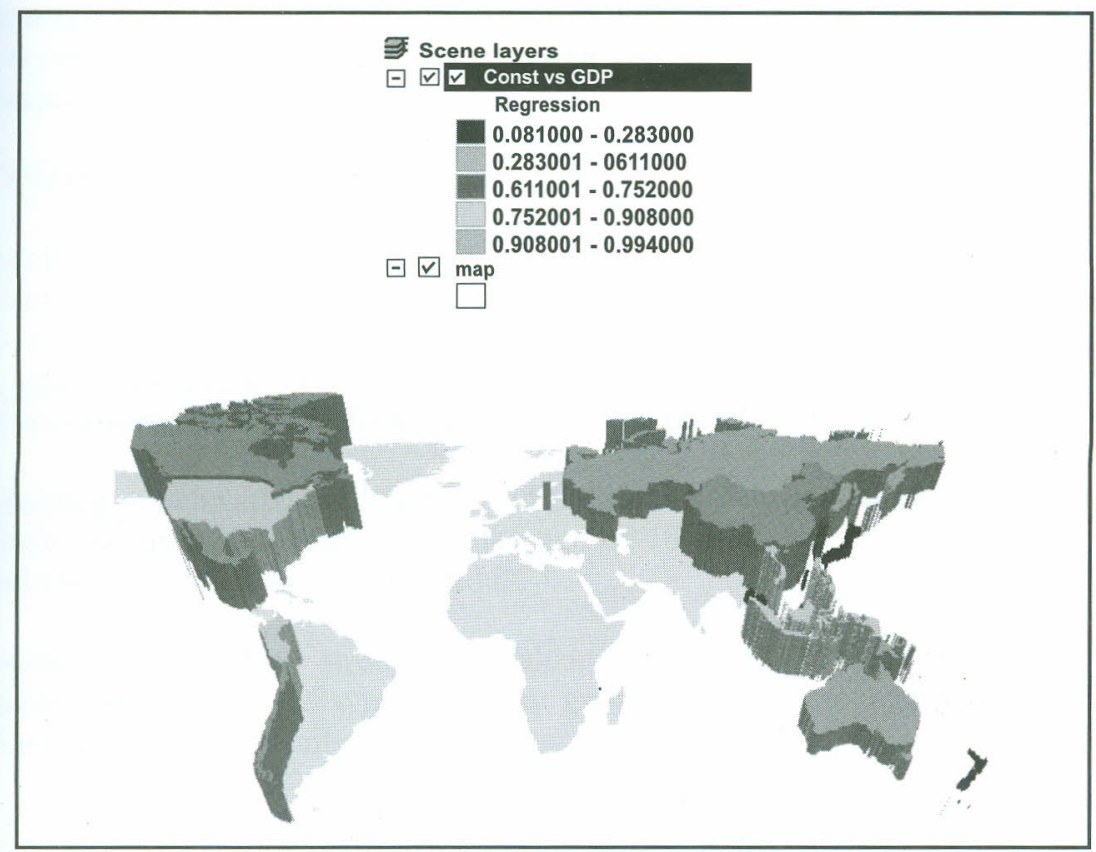

Figure 9 Relationship between construction and manufacturing 


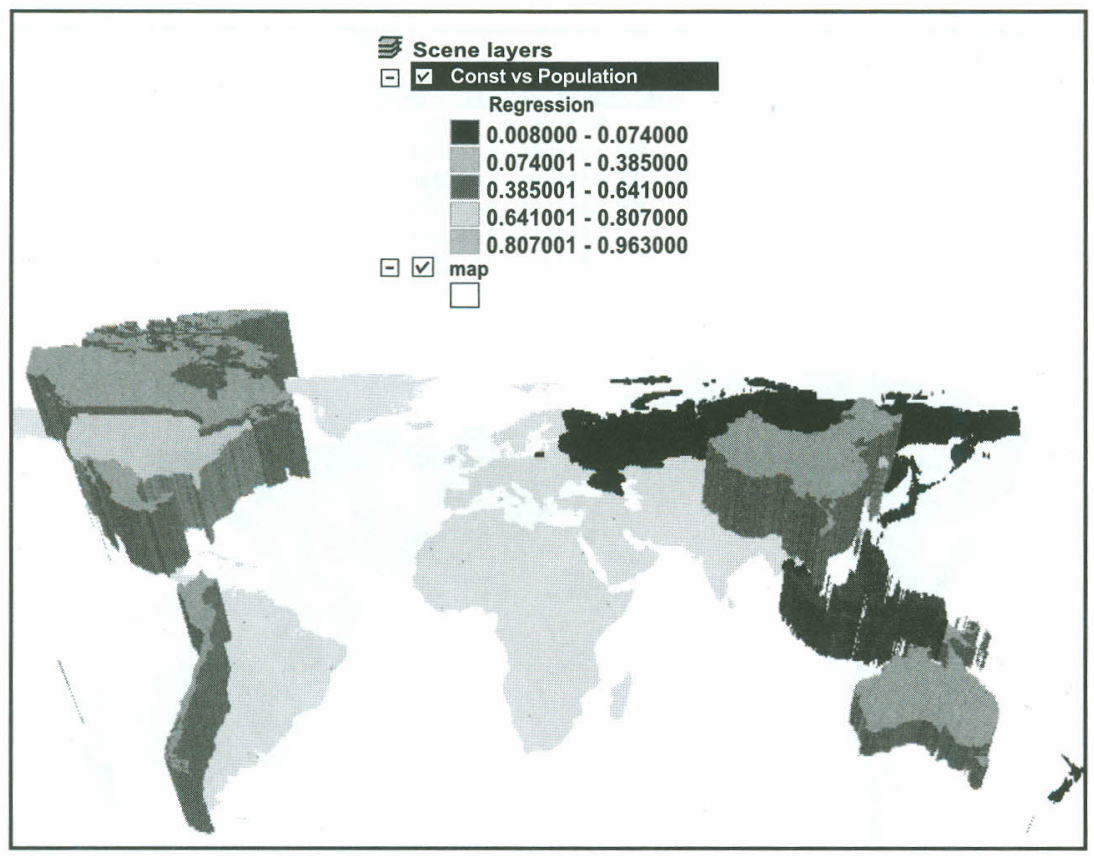

Figure 10 Relationship between construction and population 